\title{
LIVER DISEASE IN CYSTIC FIBROSIS \\ - PRESENTATION IN EARLY \\ CHILDHOOD \\ - report of two cases
}

\author{
Edna Lúcia Souza ${ }^{a}$ \\ Simone Rocha de Araújo ${ }^{b}$ \\ Melina dos Santos Teixeira ${ }^{b}$ \\ Sheila Varjão Neves ${ }^{b}$ \\ Carolina de Godoy Almeida ${ }^{c}$ \\ Ana Paula de Brito Aguiar ${ }^{d}$ \\ Luciana Rodrigues Silva ${ }^{\mathrm{e}}$
}

\begin{abstract}
Objective: Report of two cases of patients with cystic fibrosis (CF), in a multidisciplinary pediatric service in Salvador-BA, which showed early liver involvement. Description of cases: Case 1: Child, female, 23 months of age, diagnosed with CF after repeated respiratory infections during the first month of life, with airway colonization with Pseudomonas aeruginosa and important nutritional impairment. During hospitalization, it was identified hepatomegaly with increased hepatic canaliculary enzymes and aminotransferases, and imaging studies suggesting chronic liver disease. It was conducted genetic study and it was detected a homozygous DF508 mutation. Case 2: Child, female, 7 years of age, presented hepatointestinal form of CF, with histological diagnosis of cirrhosis at 3 years of age and esophageal varices at 5 years without respiratory manifestations of CF, but with nutritional deficits. It has been conducted genetic study which detected mutations DF508 and $\mathrm{G}_{542 \mathrm{X}}$. Comments: These reported cases are distinguished by early manifestations of liver and also the severity, progression and chronicity of the disease in one of them, revealing the importance of including FC in the differential diagnosis of liver disease, regardless of age, even in the absence of pulmonary disease. These cases must also alert to the importance of periodic screening for liver disease in all patients with $\mathrm{CF}$.
\end{abstract}

Keywords: cystic fibrosis, liver disease, childhood

Corresponding author: souza.ednalucia@gmail.com

a. MD, PhD Associate Professor of Pediatrics, Faculty of Medicine of Bahia, Coordinator of Pediatric Pulmonology, University Hospital Complex Professor. Edgard Santos, Federal University of Bahia.

b. Medical Student, Faculty of Medicine of Bahia, Federal University of Bahia

c. Pediatric Nutrologist, University Hospital Complex Professor. Edgard Santos, Federal University of Bahia

d. Nutrionist, University Hospital Complex Professor. Edgard Santos, Federal University of Bahia

e. MD, PhD, Full Professor of Pediatrics, Faculty of Medicine of Bahia, Chief of Pediatric Gastroenterology and Hepatology Service, University Hospital Complex Professor. Edgard Santos, Federal University of Bahia 


\section{INTRODUCTION}

Cystic fibrosis (CF) is an autosomal recessive genetic disorder ${ }^{(1)}$ caused by mutations in a gene that codifies a chloride channel called CFTR (cystic fibrosis transmembrane conductance regulator) ${ }^{(2)}$ and affects most critically the lungs, pancreas, sweat glands and Wolffian ducts. The disease occurs one in every 3,000 Caucasian newborns all over the world and it is the most common cause of progressive chronic pulmonary disease and pancreatic failure in children. ${ }^{(3)}$

The liver involvement is characterized by the production of thick bile that causes biliary obstruction and the development of fibrogenesis and progressive fibrosis and a broad spectrum of changes that goes from morphology alterations to compromised liver function. ${ }^{(4,5)}$ Alterations on the liver function may be seen by asymptomatic elevation of liver enzymes (10\%-35\%), hepatic steatosis (20\%-60\%) and focal biliary cirrhosis ( $11 \%-70 \%)$, being the last one the most severe hepatic lesions of the disease. The main factors involved in the pathogenesis of the liver disease are severe genotypes, nutritional status, malabsorption syndrome, antioxidants deficiency, additional hepatic lesion by a hepatotropic virus, sclerosing cholangitis, autoimmune hepatitis, parenteral nutrition, druginduced liver toxicity, surgery and the presence of modifying genes. ${ }^{(6)}$

The new medications and better comprehension of Cystic Fibrosis increased survival of the patients and the occurrence of other complications such as hepatobiliary manifestations, which became more frequent. ${ }^{(4)}$ The liver disease affects one third of the patients $^{(7)}$ and it is the third cause of death in cystic fibrosis ${ }^{(8)}$ despite the lack of association with severity of the pulmonary disease.(2) Most studies describe the beginning of liver manifestations in cystic fibrosis at the first decade of life, mostly between the fourth and sixth year. ${ }^{(9)}$ Less than $1 \%$ of the patients with cystic fibrosis have clinical or laboratorial evidence of hepatic impairment in the first decade of life. Even in this age group the symptomatic form of liver disease has been very rare and published in less than $5 \%$ of the cases so far. ${ }^{(10)}$ In necropsy, identified fibrosis has been reported in about $27 \%$ of infants and up to $70 \%$ in young adults. ${ }^{(11)}$
This article reports two cases of CF with early liver involvement, both followed up at the Ambulatório Multidisciplinar de Fibrose Cística do Complexo Hospitalar Professor Edgar Santos (ComplexoHUPES), Salvador, BA. This study was approved by the Internal Review Board of Hospital Professor Edgar Santos, under protocol number 385.027 .

\section{CASE REPORT 1}

FVBS, female, 4 months old, referred to the ComplexoHUPES because of her severe malnutrition with suction difficulties and delayed psycomotor development, besides diarrhea. That patient was born at term, cesarean delivery due to oligohydramnios, with history of persistent dry cough since one month old and recurrent respiratory infections that led to three previous hospitalizations. At 2 month old she was admitted at the ICU for 5 days due to water-electrolyte imbalance and urinary tract infection by Pseudomonas aeruginosa. Abdominal CT showed hepatic steatosis; Chest $\mathrm{x}$-ray showed pulmonary hyperinflaction and head CT was without alterations.

Due to this history, clinical suspicion of CF was come to and a chloride sweat test was made with results of 110 and $104 \mathrm{mEq} / \mathrm{L}$ and a second sample showed 107 and $108 \mathrm{mEq} / \mathrm{L}$. After these results she was transferred to Complexo-HUPES.

Family History: Mother with history of miscarriage at 4 month pregnancy and one other pregnancy without complications. The patient's seven-year-old healthy brother had normal sweat test.

At physical examination, there was both general and nutritional poor status, tachydyspnea, persistent cough and palpable liver $3 \mathrm{~cm}$ below right costal margin.

Follow-up: At Complexo-HUPES was initiated pancreatic enzymes replacement providing good response with gradual and constant weight gain. The blood culture showed Staphylococcus aureus (MRSA) and at the oropharyngeal culture Pseudomonas aeruginosa e S. aureus (MRSA) were isolated and properly treated. The child had improvement of the 
respiratory status. During all the hospitalization time, she kept high values of canalicular enzymes and serum transaminases and the ursodeoxycholic acid was prescribed. Genetic study showed homozygosis for the $\Delta \mathrm{F}_{508}$ mutation.

After hospital discharge she was regularly followed up, evolving with important improvement of the nutritional status. She is currently eutrophic. After the use of ursodeoxycholic acid there was improvement of transaminases and GGT levels but there are still high values of alkaline phosphatase (Table 1). Recent ultrasound evaluation showed normal abdomen and at the physical examination there was palpable liver $2,5 \mathrm{~cm}$ of right costal margin. A summary of laboratory results is shown in Table 1.

Table 1. Complementary Exams Case 1

\begin{tabular}{|c|c|c|c|c|c|}
\hline & $03 / 23 / 2012$ & $04 / 11 / 2012$ & $05 / 11 / 2012$ & $08 / 18 / 2012$ & $05 / 06 / 2013$ \\
\hline $\operatorname{AST}(U / L)$ & 81 & 135 & 47 & 42 & 58 \\
\hline $\operatorname{ALT}(U / L)$ & 60 & 123 & 49 & 32 & 28 \\
\hline GAMA GT $(U / L)$ & 696 & 1249 & 490 & 36 & 12 \\
\hline $\begin{array}{r}\text { AlkaliNe } \\
\text { Phosphatase }(U / L)\end{array}$ & 333 & 566 & 373 & 773 & 1120 \\
\hline $\begin{array}{r}\text { ProthrombIN } \\
\text { TIME }(\%)\end{array}$ & $56 \%$ & $86 \%$ & & $86 \%$ & $100 \%$ \\
\hline ALBUMIN $(g / d L)$ & 2,0 & 2,5 & 3,9 & & \\
\hline $\begin{array}{r}\text { Conjugated } \\
\text { BiliRubin }(\mathrm{mg} / \mathrm{dL}) \\
\end{array}$ & & 0,16 & & & \\
\hline $\begin{array}{r}\text { UNCONJUGATED } \\
\text { BILIRUBIN }\end{array}$ & & 0,21 & & & \\
\hline $\begin{array}{r}\text { ABDOMINAL } \\
\text { ULTRASOUND: }\end{array}$ & \multicolumn{5}{|c|}{$\begin{array}{l}\text { 04/16/12 - Echographic signs compatible with chronic parenchymal liver } \\
\text { disease, with hepatomegaly, both related to primary disease.Hydronephrosis } \\
\text { grade I at left.Hipoechogenic areas peripiramidais in both kidneys }\end{array}$} \\
\hline Chest X-RAY & \multicolumn{5}{|c|}{ Pulmonary hyperinflation } \\
\hline $\begin{array}{r}\text { OROPHARYNGEAL } \\
\text { CULTURE }\end{array}$ & \multicolumn{5}{|c|}{ Positive for Pseudomonas aeruginosa e S. aureos (MRSA) } \\
\hline BloOd Culture & \multicolumn{5}{|c|}{ Positive for Sthaphylococcus aureos (MRSA) } \\
\hline $\begin{array}{r}\text { SWEAT TEST } \\
(\mathrm{mEq} / \mathrm{L})\end{array}$ & \multicolumn{5}{|c|}{$\begin{array}{l}14 / 03 / 2012 \text { - 110/104 } \\
22 / 03 / 2012 \text { - 107/108 }\end{array}$} \\
\hline
\end{tabular}

\section{CASE REPORT 2}

EOL, female, 5 years and 10 months old, with history of low weight gain since birth, steatorrhea and diarrhea since 2 years old. The child complained that she had recurrent pain abdominal and abdominal distension in that same period of time and symptomatic hypoglycemia. After a clinical evaluation and ultrasound showing hepatomegaly, she was referred to Complexo-HUPES. 
Family History: Mother with history of four pregnancies and four deliveries, two deceased sons, one at his first year old by pneumonia and other due to anemia of unknown cause.

Cystic Fibrosis was a differential diagnosis of liver disease with malnutrition and history of steatorrhea. To confirm the hypothesis was requested a sweat test that was positive in two samples and pancreatic enzymes replacement was initiated. Liver biopsy showed cirrhosis and ursodeoxycholic acid was prescribed. Genetic study detected $\Delta \mathrm{F}_{508}$ and $\mathrm{G}_{542} \mathrm{X}$ mutations and high digestive endoscopy showed esophageal varices that were treated with propranolol.
Follow-up: Patient did not have any episodes of lower airways infections or digestive bleeding, without jaundice or hepatomegaly. Nutritional evaluation is compromised because of the hepatomegaly. At the beginning of the follow-up the growth indexes showed short stature $(H / A, Z$ score $=-2,66)$ but with adequate IMC ( $Z$ score $=0,15)$. After the introduction of pancreatic enzymes and nutritional orientations there was an improvement in the growth index $(\mathrm{H} / \mathrm{A}$, $Z$ score $=-1,45)$ with adequate IMC ( Z score $=-0,35)$ being considered an eutrophic child. A summary of laboratory results is shown in Table 2.

Table 2. Complementary Exams Case 2

\begin{tabular}{|c|c|c|c|c|c|c|}
\hline & $06 / 11 / 2009$ & $09 / 08 / 2009$ & $08 / 12 / 2010$ & $07 / 08 / 2011$ & $09 / 06 / 2012$ & $08 / 29 / 2013$ \\
\hline $\operatorname{AST}(U / L)$ & 82 & 42 & 34 & 35 & 38 & 45 \\
\hline $\operatorname{ALT}(U / L)$ & 61 & 57 & 32 & 19 & 37 & 26 \\
\hline GAMA GT $(U / L)$ & 67 & 70 & 31 & 46 & 38 & 38 \\
\hline $\begin{array}{r}\text { AlKaLINE } \\
\text { PhOSPHATASE }(U / L)\end{array}$ & 306 & 239 & 238 & 213 & 249 & 696 \\
\hline $\begin{array}{r}\text { PROTHROMBIN } \\
\text { TIME }(\%)\end{array}$ & $52 \%$ & $79 \%$ & $79 \%$ & $65 \%$ & $62 \%$ & \\
\hline ALBUMIN (g/dL) & 4,2 & 4,0 & 4,0 & 4,4 & 3,9 & 4,3 \\
\hline $\begin{array}{l}\text { CONJUGATED } \\
\text { BILIRUBIN }(\mathrm{mg} / \mathrm{dL})\end{array}$ & 0,1 & 0,2 & 0,19 & 0,16 & 0,3 & 0,03 \\
\hline $\begin{array}{r}\text { UNCONJUGATED } \\
\text { BILIRUBIN }(\mathrm{mg} / \mathrm{dL}) \\
\end{array}$ & 1,1 & 0,2 & 0,31 & 0,23 & 0,3 & 0,3 \\
\hline $\begin{array}{r}\text { ALPHA-FETOPROTEIN } \\
(\mathrm{ng} / \mathrm{mL}) \\
\end{array}$ & & & & 1,86 & & \\
\hline $\begin{array}{l}\text { ABDOMINAL } \\
\text { ULTRASOUND }\end{array}$ & \multicolumn{6}{|c|}{$\begin{array}{l}01 / 17 / 2011 \text { - Hepatomegaly with signs of chronic parenchymal disease. } \\
02 / 07 / 12 \text { - Hepatomegaly with non-uniform texture. Diffuse fibrosis. }\end{array}$} \\
\hline $\begin{array}{r}\text { LIVER } \\
\text { BIOPSY }\end{array}$ & \multicolumn{6}{|c|}{$\begin{array}{l}\text { Extensive fibrosis and proeminent proliferation of non-dilacted biliary ducts, and a } \\
\text { polymorphonuclear cells infiltrate. Portal spaces are expanded and delimited by hepatic } \\
\text { nodules without a typical characteristic of regeneration. Hepatocytes presenting } \\
\text { macrovacuolar steatosis. No PAS positpositive material was found at diástase, }\end{array}$} \\
\hline $\begin{array}{l}\text { CULTURA DE } \\
\text { OROFARINGE }\end{array}$ & \multicolumn{6}{|c|}{$\begin{array}{l}\text { 05/12/10 - Positive for Klebsiela pneumoniae, Staphylococos sp } \\
\text { 07/26/12 - Staphilococcus aureus } \\
\text { Normal (11/08/11) }\end{array}$} \\
\hline $\begin{array}{r}\text { ENDOSCOPIA } \\
\text { DIGESTIVA ALTA }\end{array}$ & \multicolumn{6}{|c|}{$\begin{array}{l}\text { 14/09/09 - Mild Enanthematous Pangastritis } \\
\text { 18/05/11 -Tortuous distal small varices, Mild portal hypertensive gastropathy } \\
\text { 07/08/12 - Slightly tortuous Esophageal varices, up to mid esophagus. }\end{array}$} \\
\hline SWEAT TEST & \multicolumn{6}{|c|}{$\begin{array}{l}19 / 07 / 2009-114 / 111 \\
13 / 07 / 2009-95 / 90\end{array}$} \\
\hline
\end{tabular}




\section{DISCUSSION}

The liver involvement in patients with cystic fibrosis has received less attention than pulmonary and pancreatic manifestations due to its lower rate of occurrence. ${ }^{(2)}$ However, the advances in diagnosis and therapeutics resulted in the rise of life expectancy of these patients ${ }^{(12)}$ and thus giving the necessary time for these presentations to manifest and be characterized. Liver disease has been an important cause of morbimortality in this population ${ }^{(10)}$ and needs to be better known and treated.

In both cases reported one of the most important features that suggested hepatic lesion was the elevated enzymes level. Although it is a marker with low sensibility and specificity, its use represents an important tool for screening and diagnosis of liver involvement in patients with cystic fibrosis. ${ }^{(4)}$ Studies suggest that a distinction is made between two classes of patients: those who only present persistent elevations of liver enzymes associated with hepatomegaly and little alterations at ultrasound exam (case 1) and those who develop cirrhosis with or without portal hypertension (case 2), being higher the severity of the second group. (7) The rising of hepatic enzymes could happen many years before the appearance of clinical and imaging abnormalities, ${ }^{(7)}$ as it may be occurring with the patient reported in case 1 .

Most of the studies show that this involvement happens more frequently by the end of the first decade of life and there is no evidence that correlates early symptoms with pathology severity. Costa et al. (2011) observed an average of eight years old for the diagnosis of liver disease in patients with CF, being diagnosed since the age of three. ${ }^{(13)}$ The Lindblad et al study detected an even more delayed average age, about 12 years old, with the earliest presentation at 5 years old. (8) In the cases reported here the liver disease occurred really early, still in the first semester of life in case 1 and probably in the first two years in case 2 because of the complaint of abdominal distention since then.

Although it is generally presented with few or no symptoms, the liver involvement is considered one of the primary complications of cystic fibrosis and can influence the survival rate and quality of life of the patients $^{(2)}$, being the cause of death in $2,5 \%$ of them. ${ }^{(7)}$
The complications of hepatic disease happens in average at the second decade oflife. However, the patient reported in case 2 already presented complications at 5 years old, which demonstrates precocity in its severity too. The hepatic disease can also cause or aggravate the patient's nutritional status because of fat malabsorption, protein losses and other features of liver involvement, such as changes in the metabolism of many substances. ${ }^{(7)}$ In both cases reported the nutritional status of the children was compromised and in case 2 (the most severe) the nutritional state is still a reason of concern, confirming the influence of the liver disease in the nutritional state. It is assumed that these patients ought to be systematically evaluated searching for hepatomegaly, transaminases/ GGT elevations or ultrasound abnormalities that could suggest liver involvement. ${ }^{(2)}$

In case 2 the hepatomegaly was an early manifestation of the disease with rapid progression. This emphasizes that identifying liver disease, even if just in laboratory exams, favors an early diagnosis and possible treatment, probably slowing down the illness evolution. ${ }^{(2)}$ There are several hepatic manifestations in cystic fibrosis reported such as asymptomatic liver enzyme elevation, newborn cholestasis, hepatic steatosis, steatohepatitis, focal biliary cirrhosis, multilobular cirrhosis, cholelithiasis and cholecystitis, microgallbladder, sclerosing cholangitis, cholangiocarcinoma. ${ }^{(14)}$ Screening is imperative for these conditions.

Thus, the reported cases evidence liver involvement in early stage of childhood, emphasizing the need for periodic screening for hepatic lesion in all patients with cystic fibrosis. It is also relevant the systematic inclusion of cystic fibrosis as a differential diagnosis of liver diseases in children. The prompt diagnosis of this affection can contribute for a better therapeutic approach and consequently better prognosis.

\section{References}

1. Fagundes EDT, Roquete MLV, Penna F, Reis FJC, Duque CG. Triagem diagnóstica da hepatopatia da fibrose cística. J. Pediatr. 2002;78(5):389-96. 
2. Colombo C, Battezzati PM, Crosignani A, Morabito A, Constatini D, Padoan R, et al. Liver disease in cystic fibrosis: A prospective study on incidence, risk factors, and outcome. Hepatology. 2002; 36(6):1374-82.

3. Rowe SM, Miller S, Sorscher EJ. Mechanism of disease Cystic Fibrosis. N Engl J Med. 2005;352:1992-2001.

4. Ling SC, Wilkinson JD, Hollman AS, McColl J, Evans TJ, Paton JY. The evolution of liver disease in cystic fibrosis. Arch Dis Child. 1999;81:129-32.

5. Debray D, Lykavieris P, Gauthier F, Dousset B, Sardet A, Munck A, et al. Outcome of cystic fibrosisassociated liver cirrhosis: management of portal hypertension. J Hepatol. 1999; 31(1):77-83.

6. Colombo C, Russo MC et al. Liver disease in cystic fibrosis. J Pediatr Gastroenterol Nutr. 2006;43:S49-55.

7. Debray D, Kelly D, Houwen R, Strandvik $B$, Colombo C. Best practice guidance for the diagnosis and management of cystic fibrosis-associated liver disease. J Cyst Fibros. 2011;10(2):29-36.

8. Lindblad A, Glaumann H, Strandvik B. Natural History of Liver Disease in Cystic Fibrosis.

Hepatology. 1999;30(5):1151-8.
9. Colombo C, Battezzati PM, Podda M, Bettinardi N, Giunta A. Ursodeoxycholic Acid for Liver Disease Associated With Cystic Fibrosis: A Double-Blind Multicenter Trial Hepatology. 1996; 23(6):1484-9.

10. Colombo C, Battezzati PM. Liver involvement in cystic fibrosis: primary organ damage or innocent bystander. J hepatol. 2004;41:1041-44.

11. Moyer H, Balisteri W. Hepatoboliary disease in patients with cysctic fibrosis. Curr Opin Gastroenterol. 2009; 25:272-8.

12. Scott-Jupp R, Lama M, Tanner MS. Prevalence of liver disease in cystic fibrosis. Arch Dis Child. 1991; 66(6):698-701.

13. Costa PC, Barreto CC, Pereira L, Lobo ML, Costa MA, Lopes AIG. Cystic fibrosis-related liver disease: a single-center experience. Pediatr Rep. 2011; 3 (3): e21.

14. Sokol R, Durie P. Recommendations for management of liver and biliary tract disease in cystic fibrosis. Cystic Fibrosis Foundation Hepatobiliary Disease Consensus Group. J Pediatr Gastroenterol Nutr. 1999;28(Suppl):1-13. 